\title{
Los Alamos Plutonium Facility Applied Systems Integration Project Status Report for Period Ending August 31, 1981
}

D. G. Shirk

R. C. Bearse*

R. S. Marshall

A. L. Baker

C. C. Thomas. Jr. 
IOS ALAMOS PLUTONIUM FACILITY APPLIED SYSTEMS INTEGRATION PROJECT STATUS REPORT FOR PERIOD ENDING NUGUST 31,1981

by

ก. ก, sh́lrk, R, C. Bcarso, R. 3. harshall, A. L. Baker, and C. C. Thomas, Ir.

ABSTRNCT

The conceptual degign of an on-line, near-real-time nondestructive assay instrumentation network for the Los Nlamos plutonium Facility is complete. Analysig of instrument hlstory data indicates that the Instrument cortiflcation precedures need improvement. Analygio of exhaust 11 ter data has led to the derivation of a bulldup prediction equation that is a function of throughput. This suggeats that development of a generallited model 15 possible. A number of routine reports are now avallable from the plutonlum Facllity/Los Alamos Safoguarde syatem incluting inventories and active reports.

\section{INT RODUCTION}

The objective of this profect is to define, test, and evalue the integration of miterlals accounting and plysical protection clements into a system to enhance the safeguarding of nuclear materlals in plants such as the Los Alamos Plutontum Faclity (Th-55). Functional systems that are typical of such nuclear plants afe physical protection, plant operations, process control, matertals control, and waterials accounting. Usualiy these systems are functionally independent with one exception; the latter two are consilered to function together as the miterials control and accounting (MCEA) system. Safeguarding nuclea) materials is typically within the purviow of the physical protection (PP) and MCEA systems operating independently with the combined goal of preventing diversion of nuclear material (NM). Plant operations and process control information systems that are of potential value for NM safeguards frequently are not readily avallable for safeyurds purposes. Thus, safeguards draws on the $P P$ and MCsA systems. Which at best may be poorly coordin- ated and may not uge information avallable from other plant systems. Integration of information from the varlous systems w1ll result in increased safeguards effectiveness wlth improved responge time and assurance.

Ideally, an Integrated safeguards system design would be included in the initial design of a facility, thereby minimizing constraints on the system. However, most existing facilities would also beneflt from even a retrofitted integrated safeguards system $1 \mathrm{f}$ it were well designed and operationaliy proven. It should be apparent that, although the design of a system for existing facilities will be site specific, there wlll be features contion to all faclitiles, for example, data acquisition, data processing and data analysis, perimeter monitoring, measurement techniques, and access/egress control. Also, retrofitted systeins will probably not be ideal, tradeoffs in design will result fran a variety of factors.

An integrated safeguards system supports the facllity management function in which a number of subsystems collect, evaluate, and transfer information to a facility data coordination center (FDCC). 
The Focc, in confunction with the subsystems, initiates appropriate responses to the trangferred information. The systems concept 11lustrated in Fig. I is for a site with a single safeguarded facility. For a site such as Los Alamos with a number of separate safeguarded facllities, the FDCC would transfer information to a site (Laboratory)wide safeguards and security system. An economcally attractive alternatlve for sites with multple safeguarded facilities is to use the computer power avallable with the materials access area (MNA) and PP data handling systems to perform the functiong of the FDCC, thereby eliminating one link in the communications chain with the site-wide system. Discusalons with both Los Alamos and other Department of Energy (DOE) facility peraonnel indicate that this latter approach is probably preferred.

The destgn of an integrated system for a prototypical plutonium processing facility using TA-55 as a base Ilne was undertaken jointly by Sandia National Laboratorles and Los Alamos National Laboratory. The system as designed, though effective, was impractical for retrofitting to the actual facllity, Heavy rellance was placed on physical protection techniques in part because of the advanced developmental state of "such techniques vis-à-vis MCGA techniques.

Development and evaluation of alternative integrated safeguards systems that could bo'implomented in the existing facility and that uge move advaticed MCkA tochnlques than those currently in use were recomended as a sequel to the initial study and are in progress. The program is to design and demonstrate an Integrated safeguards gystem that is both effective and conceptualiy, acceptable to the facility operators. The target date is September 1984. The initial effort concentrates on perfecting the rapid-inventory capabilities of the, 2A-55 materials control and accountability system, making inventory and related data available in near-real-time in a format usable in an integrated system, while assuring the integrity of the accountability data. The current tasks include development of on-line, near-real-time nondestructive assay (NDA) instrument networkg, holdup measurement systems, and a rapid physical Inventory and materials balance capability. This

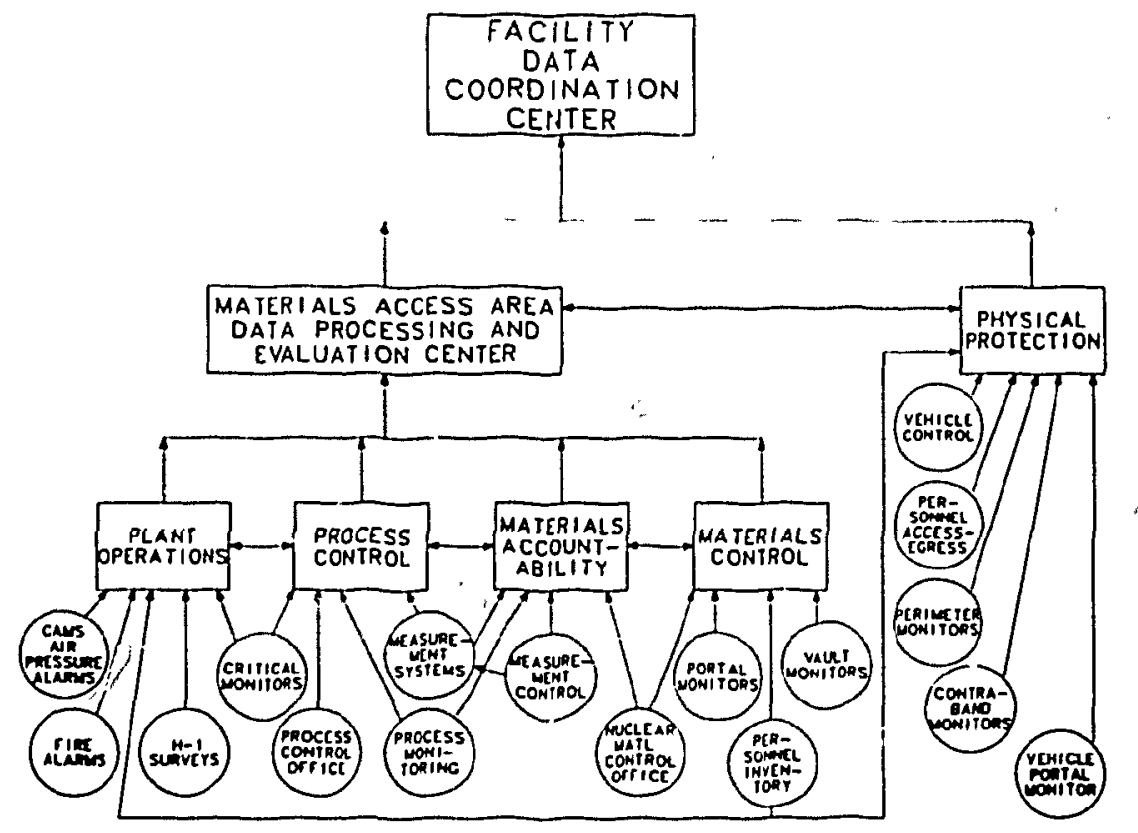

Pig. 1. Conceptual integratcd safeguards system. (Arrows indlcate information flow.) 
II. DEVELOPMEN'T PROGRAM DESCRIPTION

The basic approach to an integrated anfeguards system that could be implemented at TA-55 and the planned development program are described in the following paragraphs. Because the major effort w1ll be the development of more advanced MCsin techniques, the discussion emphasizes that aspect of the program.

The computer syetem currently envisioned for the MAA data acquisition, processing, and evaluation functions is a distributed processing system: groups of NDA instruments and terminals in the plant production and support arcas would be connected to minicomputers that, in turn, would be connected to a main computer (prasumably the existing Plutonium Facility/Los $\Lambda$ lamos Safeguards system [PF/LASS] computer). The functions of the main computer would include (1) maintenance of materials and peraonnel Inventory data bases, (2) malntenance of a materials control program data base, (3) processing of inquiries and report generation, (4) provision and analyses of near-real-time materlals accounting data, (5) coordination of data from the MAA subsystemg, and (6) trangfer of data to the FDCC or, alternatively, coordination of the MAA data with the PP data for transfer to the sitewide system and facility operations.

The main computer will not be involved in the crntrol of instruments or $1 n$ the generation of transaction records, thus releasing the main comruter for other activilles. Minlcomputers, serving as preprocessors, w111 act as instrument control devices and will also process data from terminals and measurement instruments. These processed data will then be used to update the main computer data base. This structure would release the maln conputer from dealing with instruments directly, although it could respond to inquiries abuut system-wide instrument status by querying the preprocessors.

Th1s type of distributed processing system is more versatile than the present $T r-55$ system in that it has the option of easlly handling new and deferent tasks and additlonal instruments. It is also more efficient in that operator delays are reduced because computer system äcicess is improved.
It is also more reliable, for example, if the main computer should be unavaliable for use, the preprocessor computers would store the data unt1l the main computer is back on-11ne. It also has much moro growth potentiall the addition of dozens more instruments would require that the main computer look at only one more preprocessor computer.

Computer security prublems associated with a distributed processing system will have to be ardreaged in the develnment program. It has hern assumed, for purposes of this study, that the entire system will be within a single secured facility, thus eliminating problems asgociated with transmission lines crosging unsecured areas. It is posglble, however, that an integrated safeguards system at TA-55 w111 communicate with the Los Alamos Central Alarm station and LASS, necessitating secure communications links. This possibility will be considered at an appropriate point in the development program.

The subsystems that are components of an integrated safeguards system (F1g. 1) include physical protection, materials control, materials accountability, process control, and plant operations. TA-55 contains all of the basic subsystems shown in F1g. 1. These subsystems, however, are not fully integrated, we plan to demonstrate that Integration of the existing subsystems with the addition of selected procedures, techniques, and instrumentation can produce a complete and balanced integrated safeguards system for $T h-55$ and similar generic facilities.

Any interference with process operation in a production faclitity such as Th-55 mut be minimized, consistent with operational safety and safeguards requirements. Thus, developmental studies at $\mathrm{TA}-55$ are severely constralned. To avold this congtraint, the program will be conducted using a digital computer" and its subsidiary processors as a prototypical test bed. This will provide the opportunity to develop and demonstrate components, elements, subsystems, Integration impact, effectiveness, and tradeoffs in a reallatlc yet nonoperational environment. Sengitfvity exerciges will he

*Applied Safegrards Integration Study/Test (ASIST) system. 
posaible using the away-from-plant (off-1ine) system. Because the system will be Independent of the actual facility, data bases and software support will be transportable to other facilities.

Modeling and slmulation techniques are being employed whenever practical using both mathematical " and physical models of process operations and measurement systems. The Fast Flux rest Facility (FFTF) process was selected for use as the typical TA-55 reference process, Operational dati are used In the modeling and simulation effort. Requisite components that do not exist will be designed, developed, tested, and evaluated oft-line ingofar as possible. Wherever possible and destrable, in-plant and on-line testing of new components will be performed.

The computer system for this program consists of a Digital Equipment corporation (DEC) VAX 11/780 as the main ASIST computer, a DEC PDP $11 / 34$ as bne of many posslble substdiary processors, and DEC PDP 11/03s to simulate some NDA instrumentation. New NDA 1rgtruments also will be incorporated in the ASIST system for test and evaluation.

The above program description has outlined an approach to design and demonstrate an effective and conceptually acceptable integrated safeguards system for TA-55. Rapld physical inventory/materlale balance capabilitles and holdup estimation and/or measurement are inherent parts of such a system. The capabllity to obtain rapid physlcal Inventory information anf materials balances is essential to the MCGA component of an integrated safequards system, and the development of this canability is inherent in the efforts described in this section. The estimation or measurement of in-process inventory is also an important aspect of both the MCEA and process control components of the integrated system and 13 an effort in the development progran. Holdup is a part of inprocess inventory and, after $r$ un-down and/or cieanout, may be the major part. The FY8I developrent effort has been concerned with these two activities as well as the on-11ne, near-real-time NDA instrumentation network. The status of these efforts is discussed in the following section.
III. RESULTS AND DISCUSSIONS

A. On-line, Near-Real-Time NDA Instrumentation Network

The DYMAC system (as 1nstalled at $T A-55$ ) incorporates NDA instrumentation for analyzing and verifying speclal nuclear materlal (5NM) content and Instructions for handing and measuring the SNM as it passes through the facility. Thirty-gix digltal clectronic balances, two segmented gamm scanners (SGS), three solution assay instruments (SAI), twelve operational thermal neutron counters, and twenty three terminals are located throughout the plant at strategle points. Additional instruments and termitnals are located in the vault and in the adjacent cold-support buflding where the computer is located. Operating procedures require that measurements be made and communicated to the central computer whenever a change occurs in an 1tem, such as a change in its location or physical state, or whenever an 1 tom is split or combined with another 1tem. These measurements are either typed on a terminal or transmitted directly to the computer over communications lines that cornect some of the electronic balances to the computer. For each transaction the computer uses the measurement data and the information supplied by the process technician to update the inventory data base. The invertory data base may then be querted by process techniclans and supervisors to obtain up-to-date information on the status of any item in the plant.

Although all of the NDA instruments are capable of transmitting their measurements directly to the central computer, not all of the balances have been 11 nked directly to the computer. For all the other instrunents, the process technician must note the measurement and then enter this information as part of a transaction on a PF/LASS terminal. This form of data entry not only slows processing but provides significant opportunity for recording errors, errors in data entry can result from mistyping responses by accident or can conceal a diversion attempt.

Another difficulty arlses from off-line instrumentation. Inatead of taking the time to certify an instrument before making a masurement, some process technicians make measurements with 
one instrument and then report the results using another. To reduce this tendency, a single individual has been assigned responsibllity for dally certifyling ench NDA instrument.

Thla administratlve approach is not overwhelmingly offective, however. Some process techniclans avold using the cortifled pF/LASs instruments because of the inconvenlerce of moving materlals from thele processing location to the instrument and also becauge they have to walk several times betwenn $n$ local terminnl and the Instrument to effect a transaction. From a safeguards viewpoint, all measurcment instrumentation should be on-ilne. More than a hundred instruments and terminals need access to the central computer. As $1 t$ is now conEigured, only 80 devices may be directly linkad to the computer because of software limitations. Even If all of the devices could be linked to the computer, the user response time of the system would be so degraded that the system wnuld not he usable. Currently, the system response time is barely acceptable because of the volume of transactions and process inquiries. Even lf all of the current instrumentation is brought on-11ne, the system must still provide the capablitty to handie additional uscrs and Ingtrumentation with mininum effect upon response times, and also the capability to initlate a transaction frcm a local meagurement device, or monitor.

A system is envisioned in which groups of NDA Instruments, monitors, and interactive terminals in a plant production area woruld be mnnineract to a local minicomputer. Thls minicomputer would be $A$ local node in the plant network. With thls configuration, the primary function of the central ecmputer would be to maintain a data base of all "Inventory items in the faciltty and to process inquirles to that data base from the preprocessors and arcountablitty or procassing managers. The central coriputer would not be involved in the control or monitoring of the instrumentation, nor weuld it be involved in the generation of valid transaction records. The preprocessors and local node computers wou:d perform these and other functions. A schematic diagram of the prototype network is shown in Fig. 2, A POP 11/34 wan acquired for use as the prototype preprocessor.

Conceptually, the syatem consists of a central computer with a large disk for data base manipulation, a series of preprocessors with moderate disk capacity, and at level 3, a number of NDA Instruments and terminala. Including a microprocessor in an ingtrument or monitor design is particularly Important if it must have the capability of initiating n trangnction. With the mlexuprocessor in place, changes in data entry or tranaction requirements $c a n$ be accommodated in the microprocessor software. Th1s offers the clear advantage of not burdening the preprocessor with this task. or of reguling hardware changes for the instrument or monitor. If, however, wo wish only to monitor the state of a process with a collection of sensors, then this can be easily accomplished by a multiplexor and a single microprocessor or microcomputer. Wherever possible, these instruments should be based on minicomputers or microcomputers. Elther the proprocessors or the central computer may Initiate an interchange of data with the other.

The hypothetical plant monitored by the level 1 computer istriousildered to be subdivided into several materials balance areas (MBA) (three in the flgure), each served entrely by a single preprocessor (at level 2), Each MBN must be contiguous and must not overlap any other MBA. The MBAs are further subdivided into unit processes; agaln, each unit process must be contiguous and must not overlap any uther unit process.

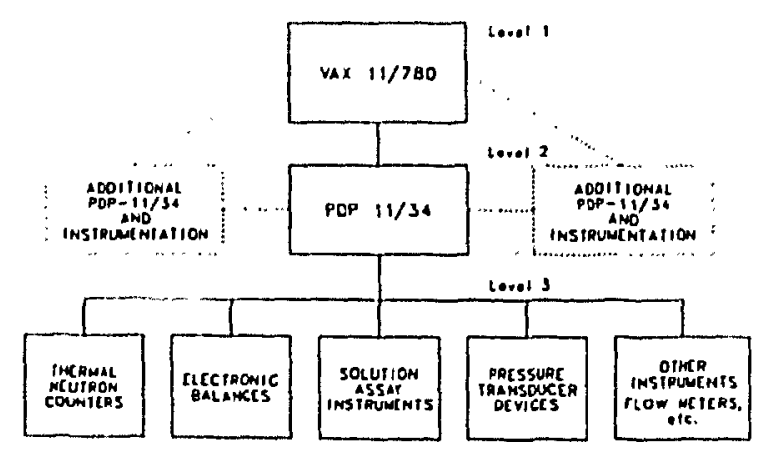

Fig. 2. Prototype network schematic. 
Whenever an 1 tem crosses a unit process boundary or undorgoes a significant change in composition, a transaction is required. The transaction is handlod by the level 2 preprocessor and after verification $1_{s}$ trangferred immeriately to level 1 (central computer). Should the level 1 computer be down, the transaction is flagged and transferred at the next oodortunity.

The level 2 computer malntalns an invantory record and a conplete Lalisaclion history for cvery J tem undergolng processing within the MBA. When the 1 tem $1 \mathrm{~s}$ transferred out of the MBA, these records are deleted after the material in process (MIP) calculation has been performed, the recelving MBA preprocessor has acknowledged recelpt, and the level 1 computer has successfully recelved the trangactions.

When an item first comes into the MBA, the initial inventory record is sent to the responsible preprocesgor by the level 1 computer. If the level 1 computer is down, the preprocessor can still initlate a transaction that is flagged to identify It as not complete because of level 1 falluro. An alternative to this simple administrative procedure is to send the transaction record directly to the recelving preprocessor. This requires an additlonal cormunications network link between the preprocessors. Additional network software and application codes would be required. clearly, this procedure would provlde a backup for the level 1 computer when it is down and a completely independent data path when the level 1 computer is operating.

This transfer of information is initiated by the trassaction that ships the material into the MaA. Consider as an example the shipment of an item fram MBA 1 to MBA 2. This action requires that two transactions be written. The first, in MBA 1, indlcates that a shipment is to travel between MBA 1 and MBA 2. The second transaction, in MBA 2, acknowledges receipt of that shipment (assuning it arrives successfully). When the sh1pping transaction 'is written in preprocessor 1 and transferred to the level 1 computer, several actions occur. The level 1 computer sends the appropriate inventory record to preprocessor 2 properly flagged to indicate that a shipment is on the way. At the same time, clocks are started in the levol 1 computer and in both preprocessors. when the shipment is rocelved, the RECEIVE transaction causes the level 1 computer to send signsls to each preprocessor that afsarm the clocks and signal the shipping Mas to delete the assoclated records.

If the recelving $\mathrm{MBA}$ does not execute a RECEIVE transaction within $20 \mathrm{~m} 1 \mathrm{n}$, the recelving preprocessor notifieg the recelving MBA supervisor. If the transaction is not logged within 30 min, the shipping MBA supervisor is notified by his preprocessor. If after $45 \mathrm{~min}$ the transaction has not been logged, the plant nuclear materlals offlcer (NMO) recelves an alarm from the central computer.

The central computer could itself handle the timing of shipments for all three computers as well as the warnings, but with the two disadvantages that (1) more Interchanges between the central computer and the preprocessors would be necessary and, more importantly,., (2) if the central computer should fall during the period of the shipment, no warnings of late shipment would be issued.

Each level 2 computer mantains a Iunning total of MIP, for each unit process in 1 ts furisdiction. The same information is, of course, avallable at level 1 . Twice each working day these numbers are compared and any discrepancies reported immediately to the NMO. This serves as an add1tional check on the safeguards integrity of the plant.

Each level 2 computer has a ligt of passwords allowing access to the computer. These passwords i.c hlerarchical: that is, supervisory passwords allow access to more privileges. For 1nstance, corrective transactions can only be made by highlevel personnel.

Each level 2 computer handles balance cert1fication for each instrument in lts MBA. The certification transactions are copled to the level 1 computer, but instrument status is malntalned at the preprocessor level.

Because some NDA instruments are not able to analyze thelr raw data, the manipulation of raw data in those cases occurs at level 2. The preprocessor has calibration information on these 
instruments and has the routines necossary to convert the raw numbers to asgay values. If the preprocessors are not to become bogged down, as much data analysis as possible must be performed at level 3. Measures should be taken to ensure the integrity of analysis and data at the instrument level. Independent veriflcation should be cons 1dered.

When a transaction 18 attempted, the preprocegsor checks the item ID to verify that it is in the inventory. Ihe preprocessor uses itg own fllos to do this veriflcation. If a new item is being created, the central computer is querled to determine if a duplication la about to occur. The need to make this check could be obvlated if all ltem ID numbers had a deslgnator for the MBA in which the new item was crented. For ingtance, the first character of an ltem ID could refer to the originating MBA. Whether this can be done will largely depend on the traditions of the target facility.

The preprocessor also malntaing a table ind cating the Instruments that can be accessed from a particular recelpt area. Transactions proposing meagurements are verified to asgure that the measurement instrument proposed is consistent with the location of the material. The transaction 18 refused if not consistent. To ensure that inoperable Instruments do not unduly impede production, the table of accessible Instruments can be modifled at the supervisory level to allow the technicians to work around such potential bottlenecks.

An effort should be made to provide some custom programs for each preprocessor to satisfy the requirements of a particular MBA. In particular, attention should be given to developing programs to assist processing at the request of the MBA supervisor(s). This effort could significantly affect the ultimate acceptance of the nenr-realtime accounting system.

The level 1 computer is almost exclugively limlted to data base manipulation and report generation. It is the final authority on what is legltimntely in the data base. It responds primarily to requesti from accountability offlcers and process control officers for reports, charts, and other output. These reports are an expansion of the types of reports now avallable at TA-55.
The goneration of MIP charti, however, can be done on-line because the central computer is almost completely unburdened from housekeeping dutieg.

The level 1 computer also responds to requests for information from the preprocessors. It is possible for an operator to request through his preprosessor that a certain report be genorated for $\mathrm{hlm}$ on the level 1 computer. The results can awalt $h / m$ at the level 1 computer or, if appropilate, car, be transmitted to him by the preprocessor. Because the level 1 and level 2 computers are both veC POP machines, there are essentially no Interfacing problems. The hardware and the software that allow Interchange of data between machines are avallable comerclally, minimizing software development needs.

The abllity to enter transaction input data from a measurement device would significantly improve operator acceptance. Currently at TA-55, trangactiong can be inftiated only from a PF/LAss CRT, which is usually located some distance from the work starion. The logistics contribute to operator frustration with the system, a losg in processing efflciency, and a much greater potential fur erroneous entrles in the transnction data basc. The comblnation of an on-line measurement device and a local, convenient means of transaction input would erhance the Intagrity of the accountability data base while Improving the use of the process technicians' time.

The ablifty to Inftlate transactions from a "primltive" device, such as an electronic balanro, pressure transducer, or flowmeter, is limited currently to the transmission of measurement data. No other flexibility exists for lata entry into the system. We have a design for a "smart" communications interfare unit that can be placed between the preprocessor and the device of interest. This unit will allow data entry by way of a compact ASCII keyboard, data output by a small thermal printer, and both on- and off-ilne operation of the device. The arbitration for the varlous options would be handled by a softwarecontrolled mlcroprocessor resident in the Interface. Additionally, the comunications signals could use elther RS-232C or 20-mA connections. This interface will allow convenient data entry 
for both process monltorling and accountabllity, while minimizing the operator effort for data entry. The compact s1ze of both the printer and the terminal will allow placement of the data entry devices at the process work station, while avolding the cost and size of a full screen CRT or hard-copy terminal.

An additional measurment device was incorporated 1nto the prototype preprocessor network - a pregsure transducer for mensuring the mass of fiuzd in a processing tank. ${ }^{1}$ The microprocessorcontrolled devlce w1ll send the tank ID and the mass of the fluld (In kilograms) in an ASCII cinaracter so that the operator may enter his ID, then the ID of the desired tank; and the pressure transducer systom will provide the information. If the cycle 18 not completed within a preset time, the procedure mugt be repeated. The tank ID is checked not only by the pressure transducer system but also upon return by the preprocessor.

To maintain the integrity of the masurement values in the transactions data base, a strlet on-11ne measurement control procedure should be adopted for the instrumentation. Measurement control instrument histories can be useful when examining MIP or cumulative summation (CUSUM) charts. To facilitate the analysis of the TA-55 PF/LASS data, analysis, graphics, and plotting codes have been developed on the PDP 12/34. These codes calculate the systematic and $r$ andom varlances for each of the digital electronic balances used In the EFTF process. Because no recallbration data were avallable, variances were plotted as a function of varying arbitrary recalibration intervals for the period March 1980 to February 1981. An example is shown in Fig. 3. In addition to this analysis, the recorded accuracy values (t statstics) were plotted as a function for each of the balances. An example of these plots is shown in Fig. 4.

With the above codes, an on-line analygis of the instrument history data base is feasible. With the graphics interpretation avallable immediately, and using the appropriate statistical trend tests, both short-and long-term trends may be visually recognized. Also, the behavior of the MIP and cusum charts can be related directly to the Instrument hlstory accuracy and precision plots.

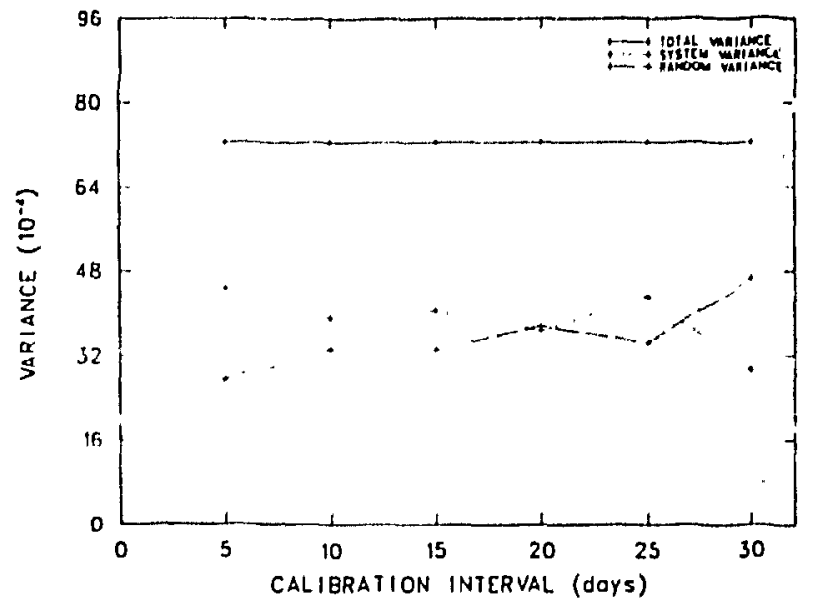

Fig. 3. Analysis of varlance; total, random, and systematic as a function of salibration interval for a atgltal electonle balance.

In addition to the enhanced accounting functions possible with the aistributed processing approach, it is also possible to improve the accounting capability of the system. Using existent data from the instrumentation and transaction records, various decision analygis techniques may be applied to detect internal diversions. The decision analysis code DECANar was installed on the prototype preprocessor PDP 11/34. It is currently belng modffied and tested to optimize performance on the PDP $13 / 34$. The output of DECANAL

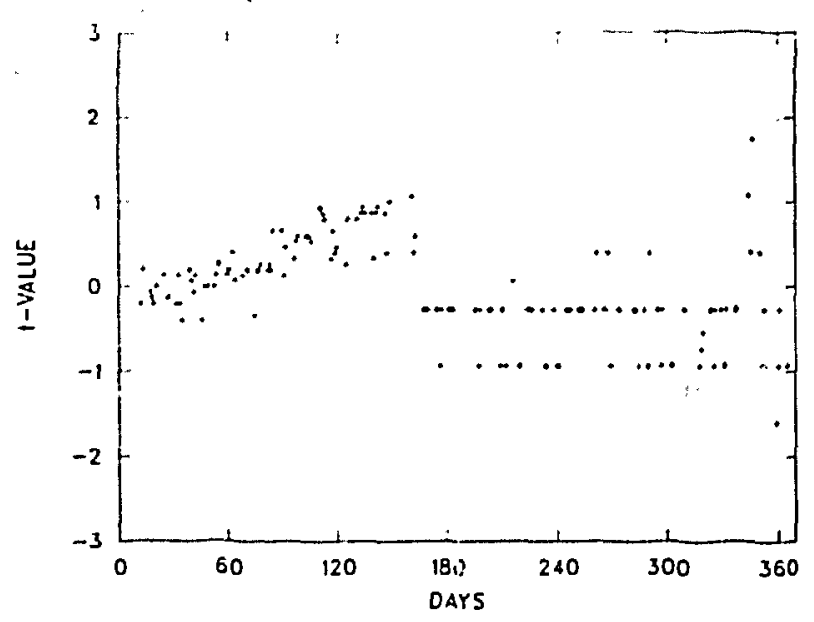

Fig. 4. Accuracy, t-value versus time parameter for digltal electronic balance. 
will take twe forms: printed reports and on-line, rcal-time color graphics. Requirements and performance criteria are belng drafted for the varlous software graphics packages. With the addition of a deciston analysis package to the preprocessor, a complete accounting, process monitoring, and accountablity system is avallable in a modular system.

The preprocessor approach with the smart interface provides slgnificant advantages over the "central computer does all" approach. A distributed systom will uliow a platis..in of a near-rcaltime accounting system. If the l1mited NDA system in a section of the plant mpets its goals while having minimum impact on the existing system, additional opportunities might arise.

The distributed system would require less elaborate coordination of the varfous goftware packages than a lone central computer. Once satisfactory protocols are developed to assure accurate and reliablo data transimission, software efforts for the preprocessor can proceed independently. Additional flexiblitty also is provided by the preprocessor approach. Reprograming for additional instrumentation or monitors çan be made to the speciflc preprocessor while not interfering with other prejrocessors or the centra* computer. This flexibllity allows a substantial period of "standalone" development time, if desired, before linking to the central computer.

\section{B. Holdup Measurement status :}

Near-real-time accounting necessitates a knowledge of in-process inventory. A potentially major component under certaln conditions is holdup. projects to develop holdup measurement techniques have been an integral part of the Los Alamos saféguards RED programs. Efforts devoted to the measurement of holdup at TA-55 presented in this section include the development of a technique for the measuroment of glovebox and equipment holdup and glovebox exhaust filter holdup.

The exhaust fliter effort has led to the derivation of a bulldup prediction equation for a particular exhaust filter. The prediction equation 1s a function of throughput. It would appear feasible to develop a generallzed model that could

$$
\text { t. }
$$

be applied to any exhaust fliter after determination of the fllter-specteic constants. The ability to estimate the amount of plutonium on a filter would permit accountability personnel to remove the filter holdup from MIP data, thus 1mproving the ability to detect protracted alversion.

The glovebox and equipenont measurement technique has been and 18 being applied to holdup measurements at TA-55 with gatisfactory results. The technique could be used to measure holdup after run-down and/or clean-out to develop base line ints for holdup prediction models. Interest in establishing such a data base has been expressed by both operations and RED personnel and was part of the motivation for the initial work in the DYMAC program. Unfortunately, time and funding limitations, coupled with a low priority relative to other tasks, have prevented investigation of the concept. Future planned evaluations of the uge of TA-55 historical data for the development of prediction models may require the use of the technique for model verification.

The inftial development of a holdup measurement system at TA-55 was mot1vated by plass to move some potentially contaninated equipment from the old plutonium faclilty (DP site) to TA-55 and an interest in establishing baseline information for plutonim bulldup studies at $T A-55 .^{2}$ The procedures developed were simllar to passive gamma ray techniques in use at the Kerr-McGee Plutonium Facility and at Los Alamos. ${ }^{3}$ The major difference is in the electronics. The TA-55 system uses a multichannel analyzer (MCA), whereas the others used a single- or dual-channcl analyzer for example, a SAM-II). 4

The TA-55 measurement technique uses a collimated 5- by 5-cm sodium lodide (NaI(TI)) detector and the MCA (Figs. 5 and 6 ). The amount of plutonium is estimated from the intensity of the ${ }^{239} \mathrm{Pu}$ garma rays in the energy region 370 to 450 $\mathrm{keV}$ and appropriate correction and calioration factors. The callbration depends on detector geometry and on the assumed distribution of plutonfun holdup as the equivalent of a polnt, liné, or area source. Attenuation corrections for glovebox walls, floors, and windows and for equipment items (for example, Incinerators) are determined using a ${ }^{137} \mathrm{Cs}$ source. ${ }^{5}$ 


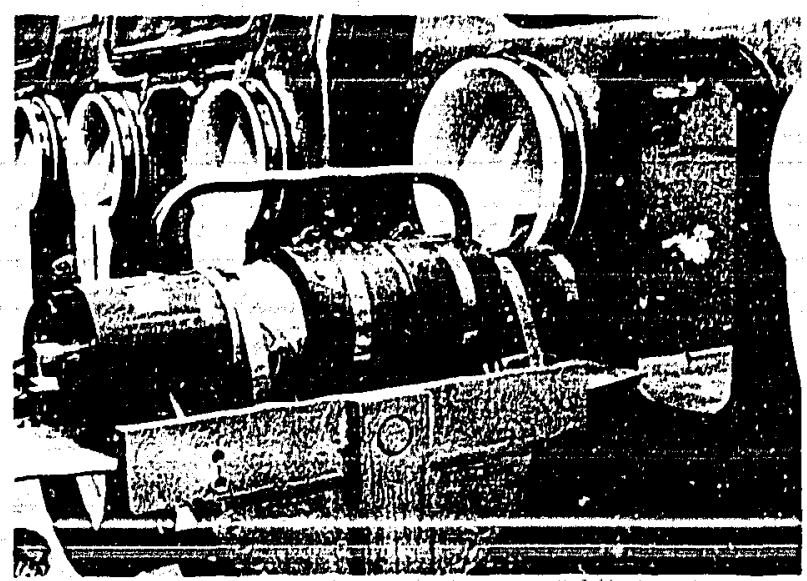

Fig. 5. Holdup measurement system detector.

The Instrumentation is moblle but not readily portable. For situations requiring a truly portable, battery-powered system, a system consisting of a collimated $2.5-$ by $2.5-\mathrm{cm}$ NaI(Tl) detector with SAM-II electronics is used.

The technique using the MCA system was used to measure the residue plutonium levels in 30 gloveboxes transferred from DP site to TA-55. As many measurements as were physlcally practical were made on all accessible stdes of the gloveboxes resulting in up to 50 measurements of 100-5 duration per box. The measurements indicated that the glovehoxes were quite clean. ${ }^{4}$ For example, elght gloveboxes had a total residual plutonium of $44 \pm 22 \mathrm{~g}\left({ }^{239} \mathrm{pu}\right) .^{5}$ An additional 12 gloveboxes indicated a total residual level of $182 \pm$ $142 \mathrm{~g}$ plutonfum. The data for the Individua 1 boxes are shown in Table I. In the calculation of tra residual plutonium, a lower-lcvel-of-detection (LLD) count was used whenever the measured count minus the background count was less than the LLD count. The LLD count is related to the background count as follows.

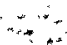

$\left.L L D=2.828 \times\left(N_{B}\right)^{1 / 2}, S\right)$

where

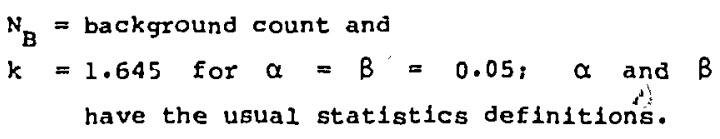
have the usual statistics definitions.

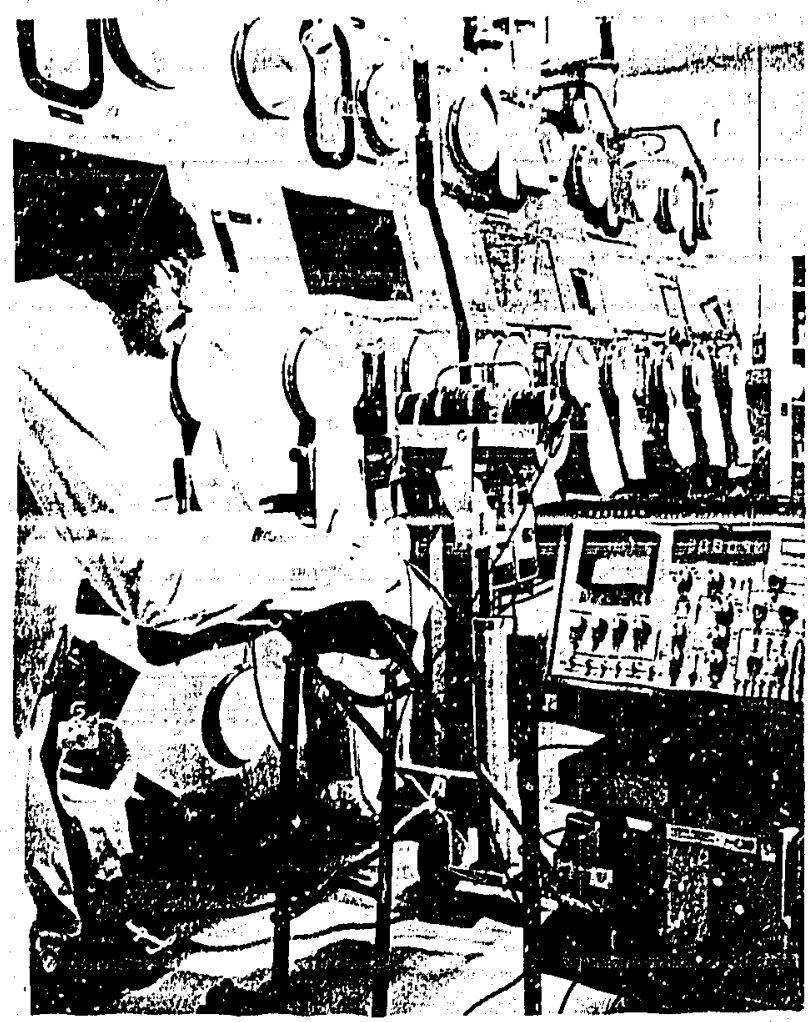

Fig. 6. Holdup measurement system.

Thus, for clean gloveboxes the residual plitonium calculated in this manner represents an upper bound on the amount of material present.

The system is used regularly upon request from TA-55 pergonnel for meaguring holdup in gloveboxes and equipment. These measurements are used for both process and accounting purposes. In general the results of these measurements are only documented Internally; however, Ref. 5 describes mean surements made on (1) two cleaned gloveboxes, $(2)$ a cleaned-out incinerator, and (3) three 36-in.dam. steel "bathyspheres."

Holdup measurements using the method described on gloveboxes and equipment in conjunction with completion of processing a batch of material weresm proposed by both operations and safeguards personnel. Such measurements could establish nominal holdups in each unit process that could then be used for in-process inventory cstimation. To date it has not been possible to 1mplement a program to carry out such measurements because of time, manpower, and funding Ilmitations. 


\section{TABLE I}

RESIDUAL PLUTONIUM LLVELS IN TA-55 GLOVEBOXES

\begin{tabular}{lc}
$\begin{array}{c}\text { Glovebox } \\
\text { No. }\end{array}$ & $\begin{array}{c}\text { Regidual PU } \\
\text { (g) }\end{array}$ \\
\cline { 1 - 2 } GB 307 & $48+5 ?$ \\
GB 314 & $16 \pm 8$ \\
GB 347, & $23 \pm 17$ \\
GB 431 & $16 \pm 10$ \\
GB 443 & $10 \pm 5$ \\
GB 445 & $10 \pm 4$ \\
GB 446 & $8 \pm 3$ \\
GB 447 & $13 \pm 8$ \\
GB 448 & $8 \pm 6$ \\
GB 449 & $10 \pm 7$ \\
GB 450 & $9 \pm 4$ \\
GB 451 & $12 \pm 9$
\end{tabular}

An in-line filter monitor has been developed and tested at TA-55 (Ref. 4, pp. 76-78; Ref. 7-9). The unit was initially installed on a glovebox in whlch $\mathrm{PuO}_{2}, \mathrm{UO}_{2}$, and carbon are blended, milled, and prepared for making advanced fast breeder reactor (FBR) fuel. Currently, the unit is installed on a glovebox in which $\mathrm{PuO}_{2}$ is screened, ground, blended, and packaged as feed material for FFTF fuel fabrication.

Glovebox alr is exhausted through at least three stages of filtrition to remove alrborne contamination. A high-efficiency particulate alr (HEPA) fliter (Fig. 7) located in a filter housing on top of the glovebox (Fig. 8) removes most of the particulate matter. Additional filtration in the building glovebox exhaust system traps any airborne particles that pass through the glovebox filter.

The in-line filter holdup monltor system consists of a 5-cm by 5-Cm NaI(TI) detector and an electronics package as shown in Fig. 9. Gama rays enfted from the filter are detected by the NaI(TI) detector and analyzed by single-channel analyzers (SCAB). Three sCAs are used for determining the plutonium gamma-ray peak area for FBR fuel. An automatic gain-control (AGC) amplifier minimizes Bhifts from counting-rate variations and photomultiplier-tube aging. The system was stablilzed by setting the SCA discriminators in the AGC

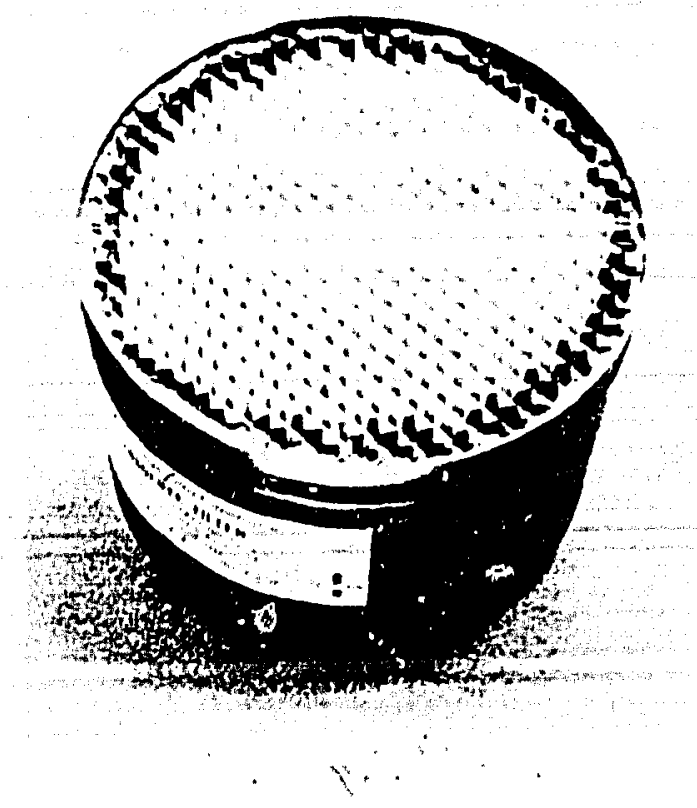

FIg. 7. HEVA f11tar.

amplifier at the $662^{-k e V}$ ganma-ray peax emieted from a 1 Hei $137 \mathrm{Cg}$ source. The SCA cutputs, including the output from the AGC amplifier, =re fed to counters that are interfaced to a printing unit. The printer is a digital printing accessory and program control center for the data acguisition bystem. The data from each counter in tha byatem are printed in sequence, with an automatic papertape advance for each new data word. By prusetting the printer to recycle and the counter/timer to a specific counting time interval, the system will continuously collect and print the data. This automatic system minimizes operator intervention once the system has been callbrated and set up for measurements. The MCA (a Facor-Northern HS-710) is used only durling the inftlal setup.

The system that was installed in the FBR fup:operation was calibrated with three plutonium fllter standards. The Los hlamos Analytical Chenistry Laboratory prepared the standards by adding known quantities of $\mathrm{PuO}_{2}$ to fllters of the same type used in the glovebox exhaust system. Each standard was prepared by sprinkling $\mathrm{PuO}_{2}$ powder evenly orer the surface of the fliter while drawing air through it, thus simulating the type 


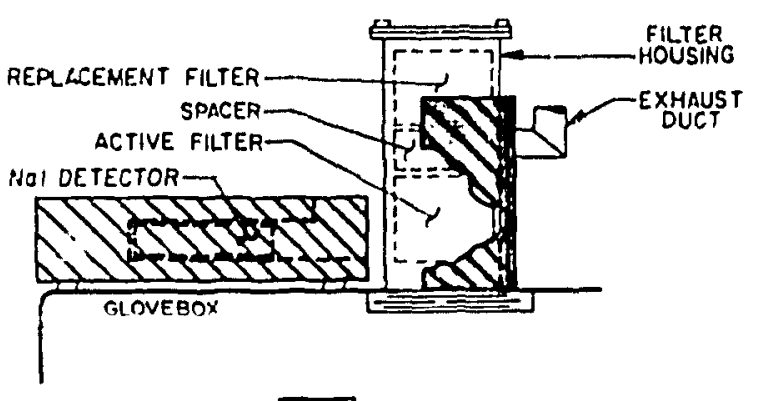

DIN LEAO SHIELOING

Fig. B. Filter monitoring system installation.

of filter loading that might be observed "In a glovebox exhaust fllter. The individual flltar standards were then sealed with aluminum foll covers packaget in double plastic bags and centered In plastlc boxes having 6-mm-thick walls. The calibration syatem setup, including detector shlelding and collimation, was the same as the In-plani setup at TA-55. Pulse plloup and deadthie corrections were deterinned using a l-wCl ${ }^{137} \mathrm{Cs}$ source. A $10 \mathrm{-g}$ reactor-grade plutonlum source was used as trangission source for mensuring sample self-attenuation."

The monftorling system successfully detected plutonium in the FBR fuel preparation glovebox ilter. The plutonius bulldup in the active HEPA filtar una monsurad durino thr preparation of 15 batches of advanced curbuse fuel. The daya were taken after each batcht if $\mathrm{PuO}_{2}, \mathrm{WO}_{2}$, and carbon had been velghed, xitxed, blended, allled, and unlobited from ball-alll jars. The results are plotted as funcelon of batch in Fig. 10(a). The bulldup is essenclally linear. The error bars represent both statistical counting uncertalneles and uncertainties assoclated with calibration. A counting tife of approxleately $100 \mathrm{~min}$ is required to obtain a statistical uncertalnty of less than ll. Figure 2n(b) shows the arount of plutonium bulldup per procussed batch. The average detected accumulation of plutonium per bach, is indicated by a dashed line, $180.096=0.037 \mathrm{~g}$.

plutonlum bulldup rate in the low-throughput Far fuel preparation-glovebox fllter was relatively

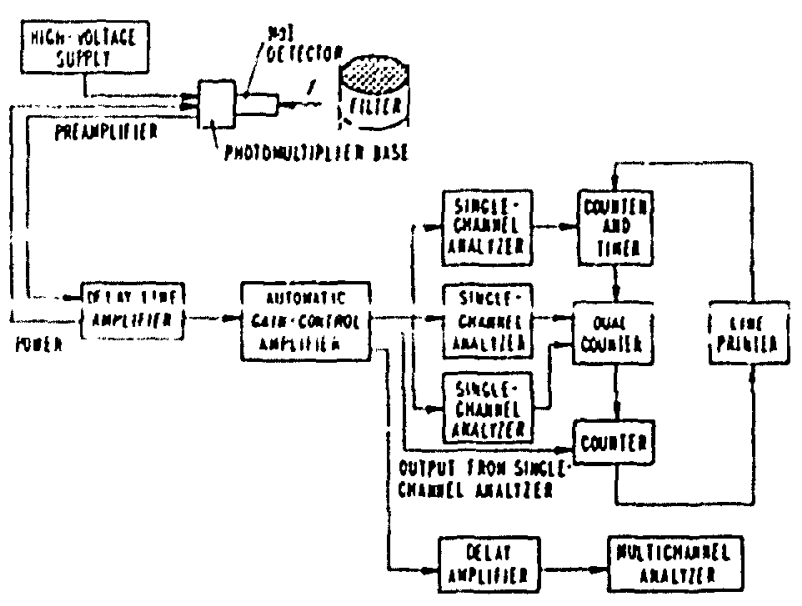

Fig. 9. Pilter monitor bystem electronics schematic.

low. At the end of 2980 the detector was relocated to monttor the plutonlu bulldup on a hlgh-throughput glovebox exhaust fllter. Filter type and orlentation and the detector installation wero identical to that al rendy described. Tho sca-based couneing system was replaced with a Canberra serles Jo MCA. The filter system sonttored from January 1981 to present has been instnlled oil a glovabox in wich $\mathrm{PuO}_{2}$ is blended, screened, and packaged. The operation 18 the last stes of a high-purity $\mathrm{PuO}_{2}$ process that ganerates $\mathrm{PuO}_{2}$ for FPT

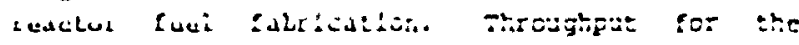
glove-box is notainily $20 \mathrm{~kg} /$ wonth. Flgure 11 shows the correlation of approximately veekly holdup measuresents with throughput. There is distinct evidence of nonilnearlty, although over the liated range of throughput, a linear flt would represent the data rather well. The holdupthroughput relationship is approxleated by a quadratic sunction (forced through the orlglin): the least-squares ist is shom it. Eq. (1).

$$
P(g)=0.1930(x)+0.0008443(x)^{2}
$$

were $x$ - tiroughput in kllograss plutoniug. 


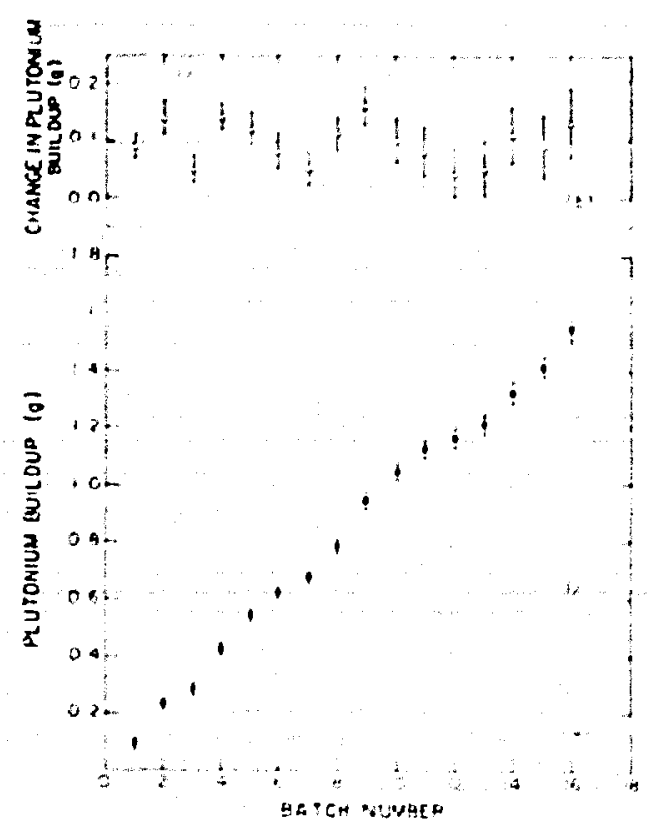

P1g. 10. Plutonlum bulldup in the glovebox exhaust I11ter as a function of bat:ch.

The 15th obaervation $(13.0,40.3) 1 \mathrm{~s}$ out of line with the rest of the data and is not used in the above quadratic fit. The ramalnder of the data are consistent. Residuit meon gquare from the flt is $\sigma^{2}=0.532$. An average standard error ovei: the ranae of throughput is $0.754-g$ plutonium. nt ligh tinroughputs (>85 kg), this is slightly iligher. Also, no evidence of variance increasing with the magnitude of response (heteroscedasticity) as would he the cane if the relative error remained constant is present over the range of the data given. Figure 11 indicates that filter holdup varies in a predictable manner as a function

of process throughput. presently, plutonium retalned by the fliters remains unmeasured (with the exception of this one filter) until the filters are replaced. Replacement frequency varies but 18 typically yearly, but may vary from 3 months to several years. Bscause the facility fllter plutonium toldup remains unmeasured for long periods, the fliter plutonium holdup is charged to a MIP account. The sumation of plutoniur holdup in all the TA-55 filters is unknown, but probably is only on the order of a few hundred grams of plutonium. charging this amount of plutonlum to Mip accounts

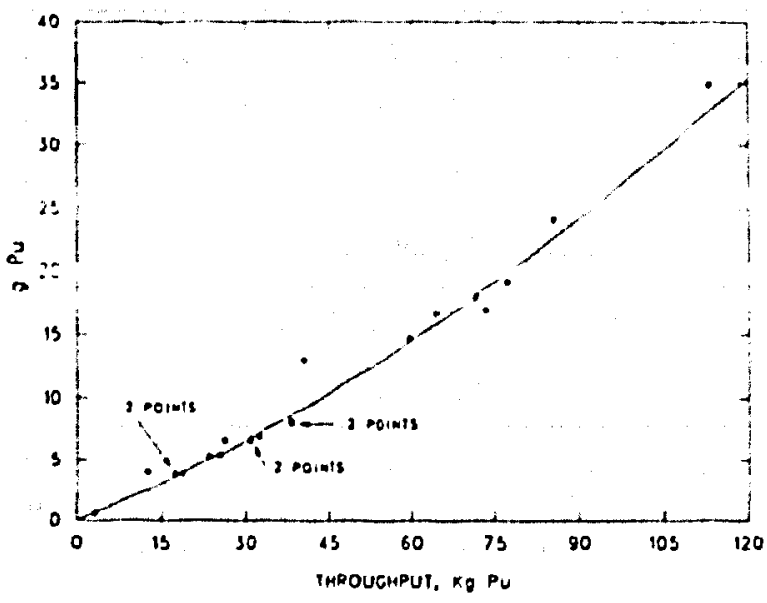

Fig. 11. Plutesnlum dioxida blending and nerouning tox fllter hesldup.

clearly reduces the ablitty of the accountablilty personnal using the MIP account data to detect protracted plutonium diversion. A program to (1) develop algorfthms to predfct plutonfum holdup on all filters versus throughput and (2) develop a computer code to calculate up-to-date plutonlum holdup on every facllity fliter would allow the ellter holdup uta to be removed from the Mip data and increase the ability to detect protracted diversion. If the Fig. 11 plutonium holdup funcliun is typiba: of aif faciithy filless, liats shep (1) of this program would be relatively simple to complete: assume the IInear holdup-throughput function for all glovebox filters and obtain the slope of the respective curves by using a 0,0 origin and a single cumulative throughput-measured plutonium holdup point. This latter point could be determined when the filters are replaced. This predictive holdup approach may be applicable to many facility items such as gloveboxes, furnaces, tanks, pipes, and ducts.

\section{Rapld Physical Inventory and Materlals Balance Status}

As noted previously the abllity to obtain rapid physical inventory information and materials balances $1 \mathrm{~g}$ an essential component of an integrated safeguards system. Th1s section reviews the current capabilities of the PF/IASS and the results of the research and development (RGD) in the areas 
TABLE II

PF/LNSS REPORTS

\section{REPORT TITIES}

on-Line

Inventury by iucatius.

Inventory by accourt

Inventory by account with remarks

Internal actlvity of 1tem

Internal activity of item with remarks

External activity of 1 tem

Item statiss

Items in transit

Tronsaction lookup

of rapld physical inventorles and materlals balance effort presently in progress. It must be emphasized that, although PF/LASS is an operational system, it is not static and the operational staff constantly is striving to improve and upgrade the system. Because of this the following discussion of the capibilities of the system represents the present situation and will change as a result of the efforts of the operational staff with or withnit the enfaginads RsD efforts.

The PF/LASS system provides a number of offline reports as well as on-line reports that are avallable to the operator on his terminal display (Table II). The off-IIne reports are available on request and, in general, contain more information about the Inventory than the on-11ne reports. The time perlod covered by this report is limited by the mass data storage and accens time capablifty of the PF/LASS computers." "e period covered by the data is currently" to 3 months. Brief descriptlons of these reports are presented in the following paragraphs.

\section{On-11ne Reports.}

a. Inventory by Location. The Inventory by Lacation report displays the current ltcm-by-item inventory for the requested location. Information about ench 1tem Includer account, materlal type, ltem fdentification (ID), recelpt area, epecial nuclear materlal (StM) amount, bulk amount, shelf, f.tem description, operational safety limits, and seal number. The total SNM amount at the location is also included in the report.

b. The Invencory by Account. The Inventory by Account report displays the current 1tem-by-item inventory for the requested account. Information about each 1 tom Includes account, material type, Item ID, recelpt area, SNM anount, bulk anount, shelf, ltom description, and seal number. The Inventory by Account with Remarks report provides the remarks flled from the transaction in addition to the information in the Inventory by Account repurt.

c. The Internal Act1vity of Iter. The Internal Actlvity of Item report displays all transactions that have affected an inventory item during the previous 6 to 10 wks. It only displays transactions that occurred inside the plutonfum facility. The report is a useful tool for tracing errors. For each transaction, the report displays a line that gives the amount of SNM transferred, material type, ltem ID, recelpt area, location, the date the activity took place, and the transditlun rumbel absiyned. The Internal ractivity of Iten with Remarks report provides the remarks t1led from the transaction as well as the Information above.

d. The External Activity of Item. The External Activity of Item report provides information slallar to the Internal Activity report except that it pertains to external transactions, that 16 , transactions between shipping/receluing accounts 770 or 771 , or clearing account 777 and an account outside the plutoniun faclilty. Hence, this report only displays transactions for items entering or leaving the faclifty, or other special NHO transactions that also affect the atation balance.

-The term recelpt area as used at TA-55 is synonymous with the term unit process. 
o. The Item status Report. The Itom Status Raport displays information about a single Inventory Item: the account, naterial type, creation date, location, shelf, recelpt ares, profect, special dasignator, Item description. SNM amount and uncertainty, isotople weight, enrichment and uncertainty, bulk amount, moasurcment code, impur-

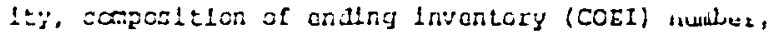
seal number, and remarks.

E. The Items in Transit. The Items in Trans1t report displays all items currently in transit in the faclitty and provides information about each: the date and time the 1 tem was sent, tho origlnating account, material type, Item ID, SNM amount, sander, and destination.

g. The Transaction Lookup. The Transaction Lookup report allows the operator to recall on his screen the full display of any transaction made in the previous 2 to 3 months. The report displays all the information in the origlnal transaction: iton ID account, recelpt area, project, sperial dealgnator, location, shelf, item description, remarks, date and time that the transaction was completed, the person(s) who made the transaction, destination, SN:! amount and material typu, bulk amount, enrichment, lsotopic weight, impurity, measurement code, seal nimber, COEI number, and Lotopes A, B, C, D, and E. However, the RESULTS summary that appears at the botton of the screen when an operator makes a transaction does not appear on a trangaction lookup.

2. Off-Line reporta. The most comprehensive off-ilne reports are Inventory by Account and Transaction Actlvity. Reports contalning Inventory information list the ltems in the current inventory with their present status and attributes. The time period for transaction activity 101 month. Transaction activity does not concern the status of Items in the current inventory, but rather gives the history of how they arrived at their current status.

a. The Inventory by Account. The Inventory by Account report is a current inventory report sorted by account, material type, and item ID. For each account it glves subtotals, by materlal type, of the SNM amount and 1sotopic weight for all accountable and subaccountable items. The total for each account only Includes accountable SNM and 1sotopic weight. A grand total of all accountable SNM and 1sotopic weight appears at the end of the

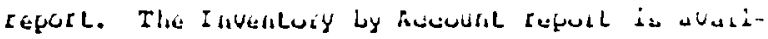
able for all or selected accounts.

b. The Inventory by Location. The Inventory by Location is a report of the inventory sorted by location, shelf, and material type. It shows the total number of 1 tems within each location. For each location it gives subtotals, by material typo, for accountable and subaccountable SNM amounts and lsotoplc welghts. The total for each location only includes accountable SNM amount and Isotoplc weight. A grand total of all accountable silm and isotopic weight appears at the end of the report,

c. The Inventory by Project. The Inventory by project report gives a printout of the current inventory sorted by project and material type. for each project it gives subtotals, by material cype, of accountable and subaccountable SHM anounts, isotoplc weights, and number of inventory ltems. The total of all accountable material for all projects included in the report appears at the end.

d. The Inventory by Special Designator. The Inventory by special Designator report provides a printout of the current inventory sorted by spcclal designator and material type. For each special designator it gives subtotals, by materlal type, of accountable and subaccountable SNM amounts, isotopic weights, and number of inventory ltems. The total for each special designator only includes accountable material. A grand total of all accountable materlal for all speclal designators included in the report appears at the end.

e. The Inventory by Item Description. The Inventory by Item Description 15 a current Inventory report sorted by account, material type, and Item description. It gives the total SNM amount 
and isotople welght for each accountable and aubaccountable material type in the account, as well as a total for all accountable materinl types in the account.

f. The Condensed Invertory. The Condensed Inventory is an Inventory report that only qives totals for the entire facility sorted by account and minterial type. It gives inventory totals of the SNM amount and 1sotopic welght for each accountable and subaccountable materlal type within every account in addition to an accountable total of SNM anount and fsotopic welght, for all material types within an account.

g. The General Ledger. The General Ledger report is an extensive summation of all the nuelear material in the facllity, sorted by materlal type and account. It lists the total sm! amount and total isotopic weight for the facllity, by material type, for each account printed. It is printed once ach processing day for the facllity's wmo. The General Ledger gives a beginning and ending balance for each material type and totala for all materlal shlpped and recelved in that material type. It also comparen the general ledger value for that materlal type with the Inventory total for the same material type.

h. The Transaction Activlty. The Transaction Activity report sorts activity, internal and external to the facllity, by "to" account, "to" materlal type, "to" Item ID, "to" recelpt area, date, and time. (Time does not appear on the printout.) it gives subtotals for the net SMs amount and isotopic welght transacted for each item whether it is accountable or subaccountable. It gives another subtotal for the net SNM and 1sotoplc weight transacted for each materlal type. It gives a total of the net amount transacted for each account.

This varlety of reports avallable for the PF/LASS gystem on either a real-time basis or wlthin a few hours is one of the major features of the system. The system provides a reasonably rapld book inventory. The timeliness of the system data base deviater from near-real-time to the extent that transactions are not nocessarliy entered into the data base at the time of tie physical trangfer of materlal. Although pF/LASS does not calculate matertals balances, the data necessary for such calculations are in the data base.

The primary succesn of PF/lass has been a decreage in the amount of time required for invencory. A boor. inventory report 18 routzneis pupared on the last working day of each week for each glovebox in the reprocessing wing and ach day for the metal fabrieation wing; the report is then confirmed by the indiviclual responstible for the area.

according to facllity staff; annual and semiannual inventories are significantly faclitated by PF/LASs. Under the paper accounting syotem used at the old facillty, the last afternoon and evening before the start of the inspection were always hectle because of the need to balance the books and to eliminate inventory items of negative mass. With pF/LASS, facillty personnel say they are so prepared for these inventories that they do not experience last-minute confusion. Furthermore, PF/LASS savos them a day at each inventory. In addition, because auditors now have avallable the means for a more reliable inventory confirmation, safeguards are improved. Now, NDA inatruments are used to confirm 1tems of inventory.

Unt1l recently, facility personnel had to perform a complete shutdown and clean-out before each physlcal inventory, halting production for 3 to wks. Scrap generated during the clean-out process must itself be reprocessed before regular production can begin again, regulting in further production loss. PF/LASS data are currently being analyzed to provide the basis for foregoing a complete shutdown and clean-out for each blmonthly and annual inventory. DOE regulations make proviston for this concept. If this concept can be demonstrated, then complete shutdown can be eliminated at a financial savings of about $\$ 1$ million per year. There have been two limited demonstratlons of this concept with satisfactory results.

Becauge of reduced errors and more up-todate book inventory, accountability of the plant is greatly improved over that of the previous faclilty. Although not all aspects of certain 
Invantary difforences are fully underatood, and although not all of tho IDA instruments are connected directly to the computer, the timeliness of the data haso is a claar improvement over the old paper system.

Some on-line accountablitey is implemented. Because processec in operation at the facility are varied and complex becauge of the RaD nature of

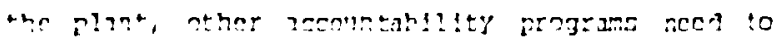
be developed and implemented recelpt area by $=-$ celpt area. Past emphasis has been on an accountIng syatem. That has now been largely achleved so that accountabllity can be given higher priority.

When processing of an item in a recelpt area is complete, the product is transferred fram the recolpt area. Material associated with sidostroams, such as waste or scrap, is also transferred either at that time or at some later time. The computer $1 \mathrm{~s}$ notified of each of these transferred itcins by means of transactions. The difference between the SNM content of item(s) entering the recelpt area before processing and the SNM ccritent of the items leaving the recelpt area after proceising is designated as MIP. When a recelpt aren has been cleared, the central computer determines the MIP (designated as MIPXX where $\mathrm{XX}$ identifles an individual recelpt areal and adds that amourit of SNM to the account that records the MIPs produced in a particular recelpt area. process technicians determlne when the MIP will be calculated; if they mistakenly claim that a recelpt area Is empty, a false value is reported.

Dynams e evaluation and graphic display of MIP data for each recelpt area are needed. Although the PF/LASS data base contalns all the information necessary for this, the capability has not been Implemented. Because graphs elearly display the accountability aspects of each recelpt area, they are a key to an effective safeguards program. The present Inability to evaluate MIPs in near-realtime is a serious deficlency that should be corrected.

To demonstrate that this capability can be developed on mediun-scale 'somputers, we have used PF/LAss data and the Q-4 Prime computer. The transaction data for the 1-yr period February
1980 to Fobruary 1981 were read into the prime computer f:im magnetle tape. After translation and selection of the set of FFTF data, programs were written to analyze these data ind calculate MIPs and CUSUMB with error propagation, including covarlances. Errors were assigned to the measurements based on a detailed analysis of the 1nstrument histories that were recorded as part of the

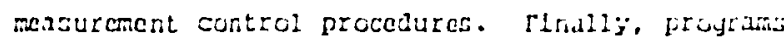
were developed for plotting these MIP and CUSUM graphs with error bars. Some examplos are show in Figs. $1.2-15$.

These graphs do not, by themselves, indicate diversion or lack of it. They do, however, 1ndicate a number of transfers that bear further analysis by the NMO. For example, the single potint in Flg. 12 arises because the measurements leading to It are reported as being made by an instrument much less precise than the balances used for all other related measurements. We cannot determine at this late stage if the measurement code was reported

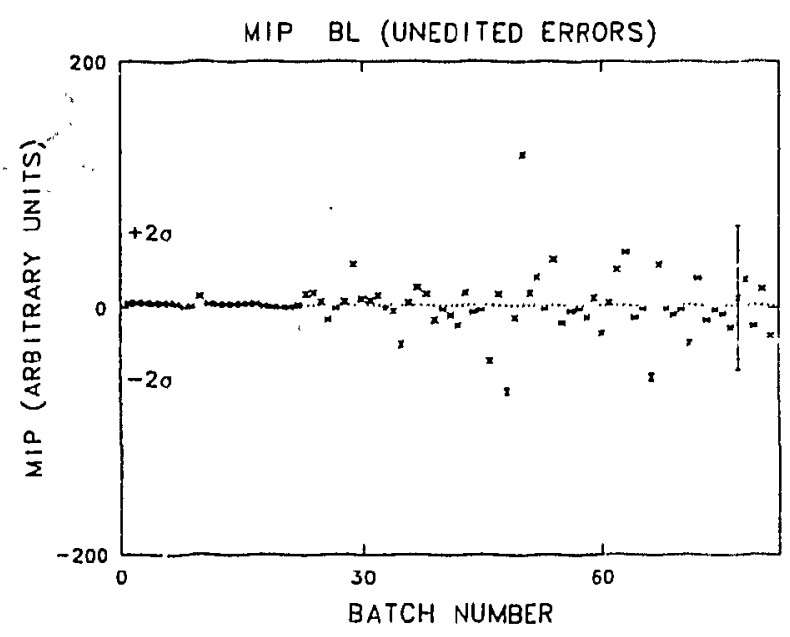

Fig. 12. A plot of MIP for the blending (BL) step of the FFTP process. Several points are well outslde the average trend and would probably be investlgated by a nuclear materials officer (NMO). The point with the large error bar is also suspicious and would trigger further study.. Our analysis indicates that the large error bar arises because of an error in reporting the instrument that was used to measure two large masses of plutonium-the difference of which was the MIP. Thls instrument was inherently much less accurate than the instruments used to measure the other points. 


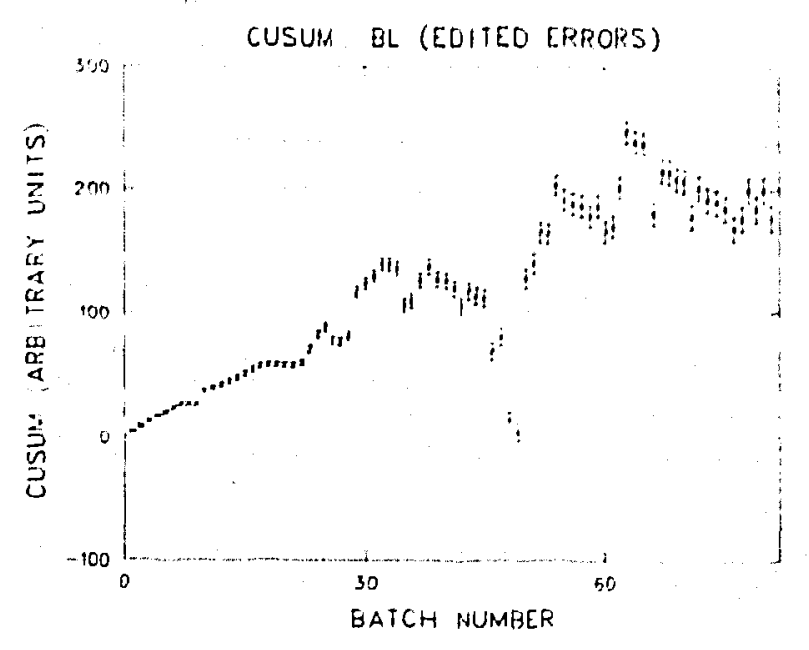

Fig. 13. A plot of the CusuM for the BL step of the FFTF process. This lilustrates how the uncertainty increases as the process operates and shows the effect of a partlal cleanout about midway through the year.

reported in efror causing us to assume an incorrect error, or whether this is, indeed, an impreclse measurement. Experience indicates that the hypothesis of an incorrect measurement code rather than an imprecise measurement is the cause of the discrepancy. In further analygis of that data, the measurement code was arbitrarily changed to a more acceptable one. Had this graph been available to the limo at the time of the transfer, he could have investigated immediately and efther corrected the measurement codt, or ensured that such imprecise measurements were not inappropriately made in the future.

\section{FUTURE WORK}

An integrated safeguards system based on TA-55 that is both effective and conceptually acceptable to Los Alamos operations will incorporate features that are equally applicable to the nuclear facilities. In addition, although $T A-55$ is a unique facility, the development of an integrated safeguards system based on that facility will provide valuable support for efforts to develop a generic, integrated safeguards system. Close cooperation

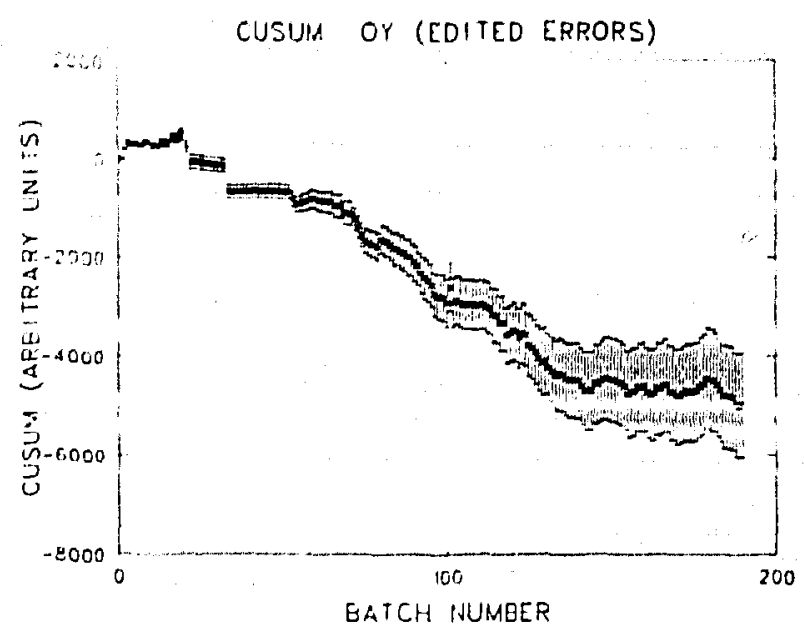

Fig. 14. The cusum for the oxolate precipitation (OY) step of the FFTF process. This atep feeds the hydrocalcination (HC) step, which is graphed in Fig. 15. The downward trend in Fig. 14 is complemented by the upward trend in Flg. 25 and probably reflects measurement bias in the thermal neutror colncidence counter (TNC) that was adapted for wet oxalate cake measurements. This instrument is used to measure the output of $O Y$ and the input of HC.

between the Individuals working on threc Los Alamos programs the TA-55 Applled systems Integration Study, the TA-55 Implementation support Ftudy, and the Sysrem Concepts Study) is so essential that, at least at times, it will be difficult to determine which study a particular effort belongs to.

With the above in mind, the direction of the future work under TA-55 Applled Syatems Integration is presented in the following paragraphs. The RKD efforts proposed as part of the systems Concepts for DOE Facilities ${ }^{10}$ will contribute to this program.

The effort Initiated in FY81 will be contlnued with emphasis on development and demonstration of a computerized MCsA data comminications gystem in the Los Alamos Safeguards RED VAX $11 / 780$ (ASIST) computer facllity. During FY82 distributed processing using real and simulated instruments, preprocessors, and the ASIST computer will be demonstrated. A data base management syaten will be implemented on the. ASIST and proven using PF/LASS data. Development of generic transaction packages will be completed during FY82. Simulation of the 


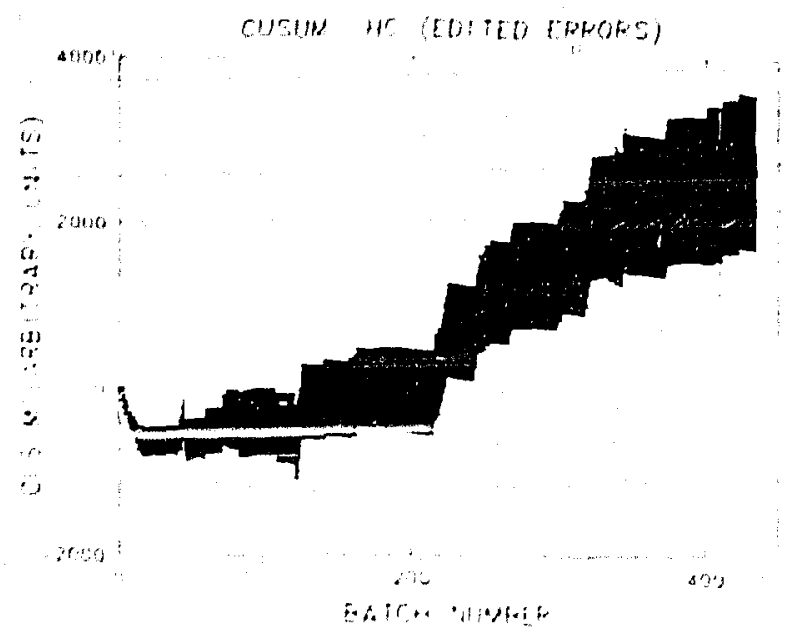

Pig. 15. Graph of the CUSUM for the HC process-should be compared and contrasted with F1g. 14 .

MC6A sygtem will be initiated early in FYB3, and simulation of the integrated system will be initiatad in FYo4. The project Review Comittec, conslating of operations and R\&D personnel, will review profect progress on a regular basia. Subsyatem developments $w 111$ be demonstrated for operatlong personnel, and where approprlate and desirable, In-plant testing will be negotiated. The office of safegurda and security will be hilefed as appropriate.

The efforts planned to achleve the goal establlshed ore the following.

1. Evaluate book inventory data on clean-outs

2. Demonstrate comunication between the proprocessor and both real and simulated Instruments

3. Complete development and installation of intercommunication software for vax, preprocessor, and smart.1nstruments

4. Evaluate use of holdup models for TA-55.

5. Decide on requirements of the data base management gystem (DBMS) and on the format of the data base

6. Implement DBMS on the VAX using PF/LASS dato
7. Complete devalogment of gonerie transaction packagas for the preprocessor

- Evaluate run-out versus clean-out book. inventory data

9. Simulate dlstributad MCsi syntems

10. Tegt and evaluate holdup models

11. Simulite full integrated cilstributed gafoquards system. Demonstrate systam $4 \mathrm{~m}$ nogotiate implementation

\section{ACKNOWLEDGAENTS}

The authors express thelr gratitude to all of the Los Nlamos personnal who contributed to this report. In particular, we offar our thanks to Denni"s Brandt, Eldon Christensen, Christopher Hodgr, Jerl Green, Ferman Kelso, Janct Coffey, Nicholas Roberts. Milton Helnberg, John Malanify, T. X. L1, Rlchard Tisinger, Mary Judy Roybal, Luclile Bonner, and Sharon Klein.

\section{REFERENCES}

itis

1. W. Ford, c. C. Thomas, R. S, Marshall, and L. Osbornu, "Solution Mass Measureinent," Los Alamos National Laboratory draft report. (SEptember 16, 1981).

2. "Nuclear Safequards Research and Develupment Progran status Report May-August 1,77," iLos Alamos Scientiflc Laboratory report LA-7030-PR (March 1970), p. 76.

3. "Nuclear Safeguaras Research and Development Program Status Report september-December 1975," Los Alamos Scientific Laboratory report L3-6316-PR (April 1976), p. 1.

4. "Nuclear Safequards Research and Development Program Status Report May-August 1978," Lns 7. Alamos scientiflc Laboratory report $\mathrm{LA}-7616-\mathrm{PR}$ (April 1979), p. 76.

5. "Nuclear Safeguards Research and Development Program Status Report July-September 1980," Los Alamos sclentific Laboratory report LA-B590-PR (March 1981), P. 35-36.

6. "Nuclear Safeguards Research and Development Program Status Report January-Apr11 1978," Los Alamos sclentific Laboratory report LA-7439-PR (December 1978), p. 80-B1.

7. "Nuclear Safeguards Research and Development Program status Report September-December 1977." Los Alamos Sclentific Laboratory report LA-7211-PR (July 1978), p. 71. 
B. Nuclear Safeguarda Regearch and Development Program Btatur Report September-December 1978," LOB Alamos sclentiflc Laboratory report LA-7706-PR (MaY 1979), p. 27-28.

9. T. K. Ll and R. S. Marshall, "An In-Line Monitor of Plutonlum Holdup in Glovebox Eliters." in Measurement Technology for Safeguards and Mater lals Control, NBS special publication 582 (June 1980), pp. 308-312.
10. R. C. Bearse, D. G. Shlrk, R. S. Marshall, and C. C. Thomas, Jr.," Systems Concepts Eor Department of Enargy Facilitlesi Research and Development Needs," Los Alamos National Laboratory draft report (September 1981). 